\title{
DÜBLIN
}

Technological University Dublin

ARROW@TU Dublin

Articles

School of Surveying and Construction

Management

2018-06-12

\section{Strategic competences for pricing quantity surveying consultancy services}

\author{
Michael Adesi \\ Technological University Dublin, michael.adesi@mydit.ie \\ De-Graft Owusu-Manu \\ Kwame Nkrumah University of Science and Technology, d.owusumanu@gmail.com \\ Róisín Murphy \\ Technological University Dublin, roisin.murphy@tudublin.ie
}

Follow this and additional works at: https://arrow.tudublin.ie/beschrecart

Part of the Engineering Commons

\section{Recommended Citation}

Adesi, M., O. De-Graft \& Murphy, R. (2018). Strategic competences for pricing quantity surveying consultancy services, Engineering, Construction and Architectural Management, vol. 25, no. 3, pg. 458-474. doi.org/10.1108/ECAM-12-2016-0264

This Article is brought to you for free and open access by the School of Surveying and Construction Management at ARROW@TU Dublin. It has been accepted for inclusion in Articles by an authorized administrator of ARROW@TU Dublin. For more information, please contact arrow.admin@tudublin.ie, aisling.coyne@tudublin.ie, gerard.connolly@tudublin.ie.

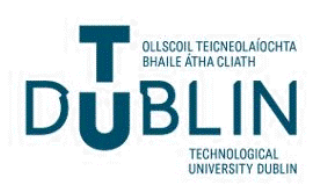




\section{e emeraldinsight}

\section{Engineering, Construction and Architectural Management}

Strategic competences for pricing quantity surveying consultancy services

Michael Adesi, De-Graft Owusu-Manu, Roisin Murphy,

\section{Article information:}

To cite this document:

Michael Adesi, De-Graft Owusu-Manu, Roisin Murphy, (2018) "Strategic competences for pricing quantity surveying consultancy services", Engineering, Construction and Architectural Management, Vol. 25 Issue: 3, pp.458-474, https://doi.org/10.1108/ECAM-12-2016-0264

Permanent link to this document:

https://doi.org/10.1108/ECAM-12-2016-0264

Downloaded on: 12 J une 2018, At: 06:21 (PT)

References: this document contains references to 82 other documents.

To copy this document: permissions@emeraldinsight.com

The fulltext of this document has been downloaded 13 times since 2018*

Access to this document was granted through an Emerald subscription provided by emeraldsrm: 156376 []

\section{For Authors}

If you would like to write for this, or any other Emerald publication, then please use our Emerald for Authors service information about how to choose which publication to write for and submission guidelines are available for all. Please visit www. emeraldinsight.com/authors for more information.

\section{About Emerald www.emeraldinsight.com}

Emerald is a global publisher linking research and practice to the benefit of society. The company manages a portfolio of more than 290 journals and over 2,350 books and book series volumes, as well as providing an extensive range of online products and additional customer resources and services.

Emerald is both COUNTER 4 and TRANSFER compliant. The organization is a partner of the Committee on Publication Ethics (COPE) and also works with Portico and the LOCKSS initiative for digital archive preservation.

*Related content and download information correct at time of download. 


\section{ECAM}

25,3

\section{8}

Received 20 December 2016

Revised 14 March 2017 10 April 2017

Accepted 16 June 2017

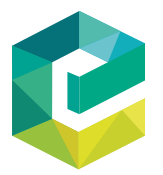

Engineering, Construction and Architectural Management Vol. 25 No. 3, 2018 pp. $458-474$ (c) Emerald Publishing Limited 0969-9988

DOI 10.1108/ECAM-12-2016-0264

\section{Strategic competences for pricing quantity surveying consultancy services}

\author{
Michael Adesi \\ College of Engineering and Built Environment, Dublin Institute of Technology, \\ Dublin, Ireland \\ De-Graft Owusu-Manu \\ Department of Building Technology, \\ Kwame Nkrumah University of Science and Technology, Kumasi, Ghana, and \\ Roisin Murphy \\ College of Engineering and Built Environment, Dublin Institute of Technology, \\ Dublin, Ireland
}

\begin{abstract}
Purpose - Professional quantity surveying (QS) services are critical to successful delivery of construction projects within planned budget, quality and duration. The supply of QS professional services is largely dependent on the price level of services and the willingness of clients to pay. The pricing of professional QS consultancy services has been confronted with a myriad of pricing challenges due to rapid changes in the business environment; the pervasive influence of information technology; and the complexity of clients' expectation. It is therefore necessary for QS consultancy firms to develop strategic competences for the pricing of their services. In addition, numerous studies have not given the pricing the pricing of professional services the requisite attention. The purpose of this paper is to investigate the strategic competences for pricing professional QS services.

Design/methodology/approach - The study was positioned within the positivist tradition. As a result, the quantitative approach was adopted using a survey questionnaire to collect data from QS consultants. The sample size of the study was 79 professional quantity surveyors chosen by using simple random sampling technique from a population of 372 registered professional QS of the Ghana Institution of Surveyors. Using the $\chi^{2}$ test and factor analysis, the study established relationship between strategic competences and pricing of QS services.

Findings - The study found that strategic competences for pricing QS professional services is significantly related to the managerial and professional competence of QS consultants. The strategic competences of QS consultants identified by this study include business management, services cost management; and production capabilities.

Practical implications - This study provides an empirical basis for QS consultancy firms to focus on strategic direction of their contractual arrangement with clients. Practically, resource configuration and on strategic competences for professional service pricing would create price leadership.

Originality/value - The study advances the pricing knowledge within the QS practice by demonstrating the nexus between strategic competences and the pricing of QS professional services which hitherto this study have not been effectively investigated.
\end{abstract}

Keywords Organization, Management, Construction, Strategic management, Estimating

Paper type Research paper

\section{Introduction}

Strategic competence is a combination of organizational and individual abilities to undertake various tasks within the constraints of their organizations (Sparrow and Hodgkinson, 2006). In this paper, strategic pricing competences refer to those abilities that organizations and professionals must develop to accurately estimate the price of their services or products. Two strands of strategy exist: professional/technical competence and business competence (Kubr, 2002). Construction professional services firms require both 
technical competence and managerial competence in order to provide to meet clients' expectations (Nalewaik, 2012). However, the management philosophy of construction firms focused on project planning, execution (Bakar et al., 2011; Yisa and Edwards, 2002) at the detriment of business strategy and pricing which have received less attention (Nagle et al., 2016). Improving the strategic competences of pricing construction professional services drives competitiveness and profitability of construction professional services providers such as (QS) firms (Meehan et al., 2012; Hjorth and Röström, 2012). Additionally, Sporrong (2011) highlighted the importance of soft competences in managing client-consultant relationship in construction professional services delivery.

Despite the importance of generating for raising revenue and profitability for business organizations, construction professional services pricing studies are scarce compared to main stream management studies focusing on pricing (Calabrese and De Francesco, 2014; Ostrom et al., 2010). In addition, product pricing is largely perceived to be equivalent to services pricing contributing to the dearth of studies on professional services pricing (Docters et al., 2004). The unique characteristics of services such as intangibility, heterogeneity, and perishability (Lehtinen and Järvinen, 2015) make their pricing distinctly different task as compared to physical products. Construction consultancy firms including QS firms have been criticized for pricing inefficiencies (Ehrhardt and Nippa, 2005). These corporate inefficiencies in pricing construction professional services have been linked to inadequate emphasis on strategic pricing competences development (Ernst and Kieser, 2005).

Meehan et al. (2012) established a relationship between pricing competences and improved financial performance in business organizations. In this vein, pricing competence development in QS firms requires provision of adequate resources to address the strategic pricing competences of professionals (Lee and Lee, 2015; Kallay, 2012). Developing the pricing competences of professionals provide the expertise for meeting revenue targets and profitability (Intagliata et al., 2000; Chappelow, 1998). Also, pricing competence drives organizational learning, performance and differentiation of services in QS professional service firms (Aly, 2016; Chen, 2012). Organizational learning encompasses inquiry, reflectiveness and evaluation of models to establish entrenched practices in organizations (Hodgson, 1998). The competence of professionals in construction consultancy firms has a positive impact the pricing of its services through a supportive network of synergy and teamwork among top management and employees of professional services firms.

The aim of this study is to investigate strategic pricing competences for QS consultancy services. In this light, the first objective was to identify the key variables for developing strategic competences of the consultant QS. The second objective was to establish the relationship between the two main strands of strategic competence for pricing QS services: managerial and technical pricing of professional QS consultancy services.

\section{Theoretical background and hypotheses}

Competence, evolutionary and capability theories have merged into competence-based theory (Hodgson, 1998) to highlight individual and team competences within the domains of skills and tacit knowledge advocated by noted scholars like Adam Smith and Karl Marx (Hodgson, 1998). Other proponents of competence-based theory included Nelson and Winter (1982) emphasizing industrial competition and development, of which professional services sector was not a primary focus. Core competence is a mechanism for developing strategic growth alternatives through problem solving to create the desired environment (Lei et al., 1996). Prahalad and Hamel (1990) provided insight on core competences in strategic management studies. Other scholarly investigations focusing on core competences include methodology of identification (Lewis, 2003); and core competences for company financial 
ECAM

25,3

cash flows (Kothari and Lackner, 2006). Similarly, practitioners viewpoints on core competence exist in Lewis (1995), Mills and Lewis (1997), Eisenhardt and Martin (2000), Porter (1998), McIvor (2000).

Strategic management theories encapsulate core competence development in business organizations. Advances in competence-based theories have been largely been credited to resource-based views in strategic management studies (Barney, 1991) of resource combination was the main approach in advancing competence theories (Rugman and Verbeke, 2002). Prahalad and Hamel (1990) identify three critical perspectives of core competences namely, access to wide and varied market; the end product or service contributing to the benefit of clients; and the difficulty of duplicating the core competences.

Competences are human characteristics for effective professional performance. Some of these human characteristics include knowledge, skills and special attributes for success in a particular endeavor. For instance, management competence model comprised of personal values and self-image; ability, knowledge and expertise; people management; and leadership (Silva et al., 2014). Anderson et al. (2008) identified nine main competences comprising relational, impartial, technical, creative, directive, tenacious, empowering, influential and strategic. Furthermore, competences are categorized as task-related, people-related, and self-related competences (Analoui et al., 2000). The pricing of construction consultancy services is task-related (Nikumbh and Pimplikar, 2014). To this study, task-related competences are key to the pricing of QS consultancy services in the construction industry. According to Vaculik et al. (2014) task-related competences underpin effective professional performance. Task-related competences drive formulation of strategic objectives; forecasting, planning and organization of tasks. It is worthy to note that pricing requires the formulation of strategic pricing objectives; and forecasting of the desirable price levels. However, it is also important to acknowledge that people-related competences are critical to effective pricing of construction QS consultancy services. Therefore, the selection and development of professional competences is fundamental to effective and strategic pricing of construction consultancy services (Brant et al., 2008).

\section{Competences for construction project delivery}

Competence is significant to successful construction project delivery. Thus, previous studies focused on competence models (Chong, 2008; Patanakul and Milosevic, 2008; Harison and Boonstra, 2009). Similarly, Vaculik et al. (2014) suggested the tailoring of specific competence models to tasks. The quest for using competence in organizational development and performance led to numerous studies in the construction industry. Notable studies focusing on competence in the construction industry include Dullaimi and Langford (1999), Dainty et al. (2004, 2005), Skipper and Lansford (2006). The aforementioned studies focused on the development of appropriate competence framework to advance the professional performance and goals (Cheng et al., 2005). In an attempt to develop the competence of professionals within the construction sector, some critical factors are necessary for consideration. These critical factors include the formulation of detailed job description; development and implementation of staff training programs; enabling working environment; and effective manpower planning and staffing (Dainty et al., 2004, 2003; Gibb, 2003).

A insight into the nature of construction consultancy services pricing requires competences that can be deployed within project duration (Chisnall, 1982). This phenomenon of pricing QS services within project duration has made construction consultancy services pricing time-sensitive as compared to manufactured goods or other services. Likewise, pricing construction consultancy services both time and material-related. In this regard, professional QS consultants the price of their services based on the time and the materials used to provide services to clients 
(Jenkins, 2006). In this direction, the amount of time spent in providing services to clients is fundamental to successful pricing of QS consultancy services. However, adopting time-based pricing strategy for QS consultancy services has some inherent risks. To mitigate the shortcomings of time-related pricing, construction consultants adopt fixed pricing strategy which requires competences for good financial control system; and accurate project information (Selfano et al., 2014). The availability of good financial control systems and a collection of accurate project information are fundamental to accurate forecasting of prices for consultancy services (The World Bank, 2002). Additionally, competences for producing timely project reports is one of the hallmarks for effective pricing of construction consultancy services (International Finance Corporation, 2007), as it is one of the justifications of prices set for services. Control systems for pricing compare the actual cost of undertaking tasks to milestones attained in the delivery of the project targets (Flyvbjerg et al., 2003). However, construction consultants such as quantity surveyors, architects and engineers have encountered problems with the control of cost in their effort to price their services provided to clients (Haider, 2009).

\section{Consultancy services pricing}

The price of professional services is one of the criteria for selection of professional services firms. The pricing of professional services is therefore linked to the procurement of construction consultancy contract (Sporrong, 2011). Thus it would suffice to assert that construction consultancy services pricing competences are required during consultation process. Consultancy services pricing is a major medium for setting specific price for anticipated services to be supplied to clients (Meissner and Strauss, 2010). In competitivebased pricing, it is necessary to demonstrate input efficiency to the client (Hamilton, 2008) to address the expectations of the consultant and the client (Dwyer and Tanner, 2006). Competitive pricing of construction professional services is complicated and leads to the adoption of cost-based strategies by some professionals like quantity surveyors. Cost-based strategies of pricing professional services has challenges; and not useful because of the numerous of cost components involved (Reguant, 2011). Similarly, it does not provide for precise setting of prices for consultancy services (McAfee, 2008). Consultants often address pricing challenges through overheads to cater for costing inaccuracies. The pricing of consultancy contract focuses on technical, financial capacity; reputation, experiences from previous works undertaken; the ability to deliver services within specified duration; and business development (Perreault and McCarthy, 2002).

From the above, it is clear that the competences for construction QS services pricing is dependent on key factors the identified by Perreault and McCarthy (2002). It is important QS consultants develop their organizations and human resources in their organizations to meet the requirements of these competences for pricing consultant QS services. The above review has revealed key competences for pricing QS consultancy services. Among these competences are financial control system, record of past costs (cost history of projects), cost forecast and timely delivery of deliverables. Therefore, upon a careful reflection on the above review and deliberations, it is appropriate to hypothesize that:

H1. The s managerial competences for pricing QS consultancy services would not require the following: (a) time taken to solve the problem, (b) materials used on the project, (c) good financial control system, (d) record of past project costs, (e) accurate forecast of future cost, and (f) production of timely reports.

Similarly, the above discussion has demonstrated the variables for developing competences for pricing construction consultancy services tenders depends on the capacities of the consultant. These capacities in no doubt affect the probability of winning a successful bid to

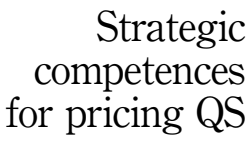

461 
ECAM

25,3

462

deliver the services sought by the client from the consultant. Hence it is necessary to place a high premium on the competences for finance, technical, previous experience, duration management; and profit and overhead build-up. Equally, it is important to develop the competences for pricing QS consultancy services tenders. The ability of the consultant QS organization to price tenders provides the opportunity to secure consultancy services projects upon which they tend to price their services. Hence it is appropriate to hypothesize that:

H2. The pricing of QS consultancy services is not dependent on the effective development of quantity surveyors professional competences in the following: (a) financial capacity, (b) technical capacity, (c) experience from previous works undertaken, (d) the capacity to deliver services within specified duration, (e) professional reputation, (f) business development, and $(\mathrm{g})$ profit and overhead build-up.

In order to provide the meanings of the independent variables in $H 1$ and $H 2$ (Table I).

\section{Research methodology}

This study adopted the quantitative research approach to enable the collection of data suitable for testing of hypotheses formulated in order to draw significant conclusions regarding the pricing competences of professional quantity surveyors. The target population was 372 registered members of the QS Division of the Ghana Institution of

\begin{tabular}{|c|c|}
\hline Variable & Definition \\
\hline $\begin{array}{l}\text { 1. Time taken to solve a } \\
\text { problem }\end{array}$ & $\begin{array}{l}\text { This is the amount of time used in dealing with organizational problems in the } \\
\text { routine management of the firm }\end{array}$ \\
\hline $\begin{array}{l}\text { 2. Materials used on the } \\
\text { project }\end{array}$ & $\begin{array}{l}\text { These are actual materials used in solving clients' problems. These include } \\
\text { stationery items among others for administrative purposes of the } \\
\text { consulting contracts }\end{array}$ \\
\hline 3. Good financial control & $\begin{array}{l}\text { A system of financial management comprising of effective planning and } \\
\text { budgeting, reporting, communication, bookkeeping including appropriate } \\
\text { staffing for control in business organizations }\end{array}$ \\
\hline $\begin{array}{l}\text { 4. Record of past project } \\
\text { costs }\end{array}$ & $\begin{array}{l}\text { This is a historical database comprising of the actual financial expenses of } \\
\text { previous projects undertaken for clients }\end{array}$ \\
\hline $\begin{array}{l}\text { 5. Accurate forecast of } \\
\text { future cost }\end{array}$ & Determining the exact cost of services for a potential consultancy assignment \\
\hline $\begin{array}{l}\text { 6. Production of timely } \\
\text { reports }\end{array}$ & $\begin{array}{l}\text { Preparation and delivery of administrative reports within the organizational } \\
\text { structure and onward transmittal to the client as schedule }\end{array}$ \\
\hline 7. Financial capacity & $\begin{array}{l}\text { The ability of the construction consultancy firm to manage its financial assets } \\
\text { in order to meet all financial requirements for providing services } \\
\text { to clients }\end{array}$ \\
\hline 8. Technical capacity & $\begin{array}{l}\text { The ability to provide services that meet the professional requirements of the } \\
\text { consultancy engagement }\end{array}$ \\
\hline 9. Firm's experience & $\begin{array}{l}\text { Skills and knowledge created in the firm as a result of previous services } \\
\text { provided to clients }\end{array}$ \\
\hline $\begin{array}{l}\text { 10. Duration to render } \\
\text { the service }\end{array}$ & $\begin{array}{l}\text { The time within which the consultancy firm is expected to provide all services } \\
\text { to the client as in the consultancy contract of engagement }\end{array}$ \\
\hline 11. Firm's reputation & $\begin{array}{l}\text { The intangible characteristics that attract good staff, clients to offer clients; and } \\
\text { shareholders to invest in a corporate organization }\end{array}$ \\
\hline 12. Business development & Positioning the organization for growth and potential consulting opportunities \\
\hline 13. Overhead and profit & $\begin{array}{l}\text { Overhead is administrative expenses incurred in managing the consultancy } \\
\text { firm including indirect expenses incurred during the services provision to } \\
\text { clients. Profits are the financial rewards for providing technical and advisory } \\
\text { services to the client }\end{array}$ \\
\hline
\end{tabular}

Table I.

Variable definition 
Surveyors (GhIS). The sample size of 79 was determined using the Kish (1965) formula as used by Adesi (2014), Bolstein and Crow (2008). The simple random sampling technique was used to select 79 respondents from the target population of the study. The choice of the simple random sampling technique for this study was based on the availability of the roll of registered members of the QS division of the GhIS. Another requirement was to number the members on the register obtained from the GhIS serially from 1 to 79 . Further to this, it is important to adhere to the requirements of simple random sampling. Two key requirements of simple random selection are the generating random number table; and entering the rows and columns of table at random. This was achieved by using the serial number, VL7745452 of an identity card generated randomly. The last two digits, 52 were choosing to represent row and column number. Using the coin, which consist of a "head" and a "tail," 5 was designated as a "head" which represent column while 2 was designated as a "tail" on the coin, thus representing a row. With this rule established, the coin was thrown and a tail showed, this implies that 2 became the second column and 5 , the fifth row on the random number table. Column 2 and row 5 were used to obtain the first random which was 3,114 . Since the survey population was 372 , only two digit random numbers were selected. The random number 3,114 was separated into two hence the new numbers were 31 and 14 . In this case the potential participant serially numbered 31 in the register was first selected by moving from right to left. The moving downwards in column two, the next random number was 2463, again from right to left, 24 was select from the register comprising of 372 . It should be noted that participants numbered 14 and 63 on the register were not selected because the total population was 372. Emphasis was also on two digits random numbers because the sample size was 79 which was a two digit number. The selection process continued until all the 79 respondents were selected. Random numbers selected by this process which were beyond or more than 79 were ignored.

The survey questionnaires were developed using the variables derived from the hypotheses formulated based on the theoretical and conceptual review. Appropriate instructions were provided to guide respondents to answer the questions. The questions were closed-ended devoid of technical terms with responses measured using Likert scale. The variables were measured using a five-point Likert scale comprising of: $1=$ not significant $2=$ less significant $3=$ moderately significant $4=$ significant $5=$ very significant. The hypotheses of the study were formulated based on the review and synthesis of existing competence-based theories and literature on project delivery competences; and consultancy services pricing. The review and synthesis of relevant literature helps in identifying variables for hypotheses formulation (Uddin and Arafat, 2016). Similarly, the literature review and synthesis for hypotheses development was clearly demonstrated in the work of Bolton and Alba (2006) on price fairness. In all, 110 questionnaires were administered to respondents to achieve the requisite sample size of 79 . In all 79 questionnaires were recovered which gave a response rate of 72 percent. SPSS was used to derive the $\chi^{2}$ test $\left(\chi^{2}\right)$ to test the hypotheses formulated. The $\chi_{\text {cal }}^{2}$ was compared with $\chi^{2}$ value $\left(\chi^{2} \alpha\right)$ obtained from the distribution table. In drawing conclusion regarding the hypotheses of the study, where $\chi_{\mathrm{cal}}^{2}>\chi^{2} \alpha$ at a particular $p$-value, the null hypothesis postulated was rejected at a significance of a given $p$-value generated by the SPSS for a variable. Variables with a $p$-value less than 0.5 were considered significant. Finally, the factor analysis was used to reduce, summarize and classify the data to identify inherent common factors of variables (Williams et al., 2012). The Kaiser-Meyer-Olkin and Bartlett's test was above 0.5 indicating the adequacy of the data for factor analysis. Three main components were extracted for analysis were business management with 45.587 percent variance; service cost management, 9.41 percent of the total variance not explained by component 1 while component three, service production capabilities had 8.673 percent not explained by component 1 and 2, respectively. 
ECAM

25,3

464

\section{Analysis of results}

This section of the paper discusses the results of the hypotheses testing. The two hypotheses were generated using theoretical framework focusing on: time taken to solve the problem; materials used on the project; good financial control system; record of past project costs; accurate forecast of future cost; and production of timely reports; financial capacity; technical capacity; firm's experience; duration to render the service; firm's reputation; business development; and overhead and profit.

\section{Hypothesis 1}

H1. The managerial competences for pricing QS consultancy services would not require the following: (a) time taken to solve the problem, (b) materials used on the project, (c) good financial control system, (d) record of past project costs, (e) accurate forecast of future cost, and (f) production of timely reports.

$H_{0}$. The managerial competences for pricing QS consultancy services would require the following: (a) time taken to solve the problem, (b) materials used on the project, (c) good financial control system, (d) Record of past project costs, (e) accurate forecast of future cost, and (f) production of timely reports.

The result of the $\chi^{2}$ test for $H 1$ above is shown in Table I. It clearly established a relationship between the pricing of professional QS consultancy services and strategic managerial competences for time taken to solve the problem $\left(\chi_{\text {cal }}^{2}=62.722, \chi_{\alpha}^{2}=12.838, \mathrm{df}=3, p<0.01\right)$; materials used on the project $\left(\chi_{\mathrm{cal}}^{2}=34.468, \chi_{\alpha}^{2}=12.838, \mathrm{df}=3, p<0.01\right)$; good financial control system $\left(\chi_{\text {cal }}^{2}=17.456, \chi_{\alpha}^{2}=12.838, \mathrm{df}=3, p=0.01\right)$; record of past project costs $\left(\chi_{\text {cal }}^{2}=50.177\right.$, $\left.\chi_{\alpha}^{2}=14.860, \mathrm{df}=4, p<0.01\right)$; accurate forecast of future $\operatorname{cost}\left(\chi_{\text {cal }}^{2}=55.873, \chi_{\alpha}^{2}=14.860, \mathrm{df}=4\right.$, $p<0.01)$; and production of timely reports $\left(\chi_{\mathrm{cal}}^{2}=43.722, \chi_{\alpha}^{2}=14.860, \mathrm{df}=4, p<0.01\right)$. Since the $\chi_{\mathrm{cal}}^{2}>\chi_{\alpha}^{2}$ at $p<0.05$, hence reject the null hypothesis $H_{O}$ at a significance level of 0.05 . This implies that a significant statistical evidence exist to suggest that pricing QS consultancy services is dependent on strategic managerial competences. Therefore, managerial competences required for pricing QS consultancy services include time taken to solve the problem; materials used on the project; good financial control system; keeping record of past project cost; accurate forecast of future cost; and production of timely reports.

\section{Hypothesis 2}

H2. The pricing of QS consultancy services is not dependent on the effective development of quantity surveyors professional competences in the following: (a) financial capacity, (b) technical capacity, (c) experience from previous works undertaken, (d) the capacity to deliver services within specified duration, (e) professional reputation, (f) business development, and $(\mathrm{g})$ profit and overhead build-up.

$H_{O}$. The pricing of QS consultancy services is dependent on the effective development of quantity surveyors professional competences in the following: (a) financial capacity, (b) technical capacity, (c) experience from previous works undertaken, (d) the capacity to deliver services within specified duration, (e) professional reputation, (f) business development, and $(\mathrm{g})$ profit and overhead build-up.

The result of $\chi^{2}$ test for $H 2$ above is demonstrated in Table II. The results indicate that a significant relationship exist between the dependent variable of developing a strategic pricing mechanism for QS consultancy services and the independent variable: core professional competences comprising of financial capacity $\left(\chi^{2}=44.734, \mathrm{df}=4, p<0.01\right.$, $\left.\chi_{\alpha}^{2}=14.860\right)$; technical capacity $\left(\chi^{2}=69.165, \mathrm{df}=4, p<0.01, \chi_{\alpha}^{2}=14.860\right)$; firm's experience 
$\left(\chi^{2}=69.671, \mathrm{df}=4, p<0.01, \chi_{\alpha}^{2}=14.860\right)$; duration to render the service $\left(\chi^{2}=52.456\right.$,

$\left.\mathrm{df}=4, p<0.01, \chi_{\alpha}^{2}=14.860\right)$; firm's reputation $\left(\chi^{2}=59.692, \mathrm{df}=4, p<0.01, \chi_{\alpha}^{2}=14.860\right)$; business development $\left(\chi^{2}=12.595, \mathrm{df}=3, p=0.06, \chi_{\alpha}^{2}=12.838\right)$; and profit and overhead $\left(\chi^{2}=41.443, \mathrm{df}=4, p<0.01, \chi_{\alpha}^{2}=14.860\right)$. Since $\chi_{\mathrm{cal}}^{2}<\chi_{\alpha}^{2}$ and the $p>0.05$, hence reject the null hypothesis, $\mathrm{H}_{\mathrm{o}}$ at a significance level of 0.05 except to the variable business development. This means that enough evidence exist statistically to suggest that the developing strategic pricing mechanisms depend on core professional competences. These core professional competences include financial capacity; technical capacity; experience from previous works undertaken; the capacity to deliver services within specified duration; professional reputation; and profit and overhead build-up.

\section{Discussion and findings}

The components in Table III represented the common factors of the variables for strategic pricing competences for professional QS consultancy services. There were three main factors, namely: component1: business management; component 2: service cost management; and component 3: services production capabilities.

\section{Business management}

Management competences are behaviors, attitudes and skills required to perform the tasks or responsibility of a particular position in an organization. Business management competences are important to professional QS services consultants. Largely, the art of managing business does not form an integral part of the curriculum of institutions focusing on built environment education. Additionally, many professional bodies do not focus on the business management aspect of their profession as compared to professional competences. This is due to the fact that the curriculum of educational institutions and

\begin{tabular}{lccccc}
\hline Independent variables & $\chi_{\text {cal }}^{2}$ & $\chi_{\alpha}^{2}$ & df & $p$-value & Decision \\
\hline 1. Time taken to solve the problem & $62.722^{\mathrm{a}}$ & 12.838 & 3 & 0.000 & Reject \\
2. Materials used on the project & $34.468^{\mathrm{a}}$ & 12.838 & 3 & 0.000 & Reject \\
3. Good financial control system & $17.456^{\mathrm{a}}$ & 12.838 & 3 & 0.001 & Reject \\
4. Record of past project costs & $50.177^{\mathrm{b}}$ & 14.860 & 4 & 0.000 & Reject \\
5. Accurate forecast of future cost & $55.873^{\mathrm{b}}$ & 14.860 & 4 & 0.000 & Reject \\
6. Production of timely reports & $43.722^{\mathrm{b}}$ & 14.860 & 4 & 0.000 & Reject
\end{tabular}

Notes: ${ }^{a} 0$ cells $(0.0$ percent) have expected frequencies less than 5 . The minimum expected cell frequency is 19.8 ; ${ }^{b} 0$ cells $(0.0$ percent) have expected frequencies less than 5 . The minimum expected cell frequency is 15.8

Table II. Managerial competences

\begin{tabular}{llllll}
\hline Independent variables & $\chi_{\text {cal }}^{2}$ & $\chi_{\alpha}^{2}$ & df & $p$-value & Decision \\
\hline 1. Financial capacity & $44.734^{\mathrm{a}}$ & 14.860 & 4 & 0.000 & Reject \\
2. Technical capacity & $69.165^{\mathrm{a}}$ & 14.860 & 4 & 0.000 & Reject \\
3. Firm's experience & $69.671^{\mathrm{a}}$ & 14.860 & 4 & 0.000 & Reject \\
4. Duration to render the service & $52.456^{\mathrm{a}}$ & 14.860 & 4 & 0.000 & Reject \\
5. Firm's reputation & $59.692^{\mathrm{b}}$ & 14.860 & 4 & 0.000 & Reject \\
6. Business development & $12.595^{\mathrm{c}}$ & 12.838 & 3 & 0.006 & Accept \\
7. Overhead and profit & $41.443^{\mathrm{a}}$ & 14.860 & 4 & 0.000 & Reject
\end{tabular}

Notes: a 0 cells ( 0.0 percent) have expected frequencies less than 5 . The minimum expected cell frequency is 15.8 ; ${ }^{~} 0$ cells ( 0.0 percent) have expected frequencies less than 5 . The minimum expected cell frequency is 15.6 ; ${ }^{c} 0$ cells ( 0.0 percent) have expected frequencies less than 5 . The minimum expected cell frequency is 19.8

Table III. Professional competences 
ECAM

25,3

466

professional bodies for engineers, surveyors including quantity surveyors is highly technical thus, neglecting the strategic competences for managing professional service firms (Russell et al., 2007). However, the Royal Institution of Chartered Surveyors recognized the need to develop business management competences of QS professionals (RICS, 2016). Despite business management competence was mentioned in Cunningham (2014), much emphasis was placed on technical and mainstream project management skills and roles. This clearly demonstrates the neglect of the business management competences by mainstream studies focusing on QS practice. This study identified business management competences which are strategic to the pricing of QS professional. The key variables identified include firms experience (factor loading $=0.648$ ); duration to render service (factor loading $=0.709$ ); business development (factor loading $=0.881$ ); and firm's reputation (factor loading $=0.580$ ).

The previous experience of professional service firms is key to procuring QS consultancy contract. Experience in managing the routine activities of the entire QS firm ensures effective delivery of services. The previous experiences of quantity surveyors provide capabilities for developing sustainable pricing strategies in uncertain business environment. The experience of firms is linked to entry into new markets and segments of services provision requiring strategic focus (Dimov and de Holan, 2010). Organizational experience enable QS firms to learn and improve their performance. Organizational learning is an integral part of organizational experience development as this enhances the experience of QS professionals. Organizational learning is fundamental to developing previous experience of firms through routine business management activities (Nelson and Winter, 1982). In a study focusing on UK construction engineering consultancy firms, Yisa and Edwards (2002) acknowledged the role of previous experience in performance assessment of construction consulting firms including individual professionals as a criteria for awarding new contracts. Thus, it is importnat to note that the previous experience of QS firms is an important factor in the development of sustainable pricing of QS services.

The client expects the professional service to be delivered within a specific duration. The issue of duration for the delivery of professional services in construction related projects is indicated in Farr and Fellow (2001) demonstrating the inverse relationship between billable time and rates for consultancy services. Changes in duration or billable time for construction professional services affect pricing variables such as cost, gross income, and volume of work. This makes the duration of professional services provision to clients by QS firms is an important variable to meet the expectations of the client. Developing competences to manage the time allocated for the delivery of professional QS consultancy services requires the professional management of project duration. Duration management techniques are therefore required in the pricing of professional QS services. The script theory has been used to developed techniques that manage events and time to the satisfaction of clients (Hubbert et al., 1995). The script theory technique has the potential of integrating pricing activities and experiences of QS professional consultants into knowledge structures that optimizes the memory of individual consultants. The scripts define client's expectations leading to the evaluation of performances during services delivery (Mohr and Bitner, 1991). The strategic use of scripts transforms the intangible characteristics of services by delivering services within duration to meet client's expectations. This would make the pricing of services justifiable and realistic to clients. Pricing scripts need to be organized hierarchically to achieve the major goals of pricing the services via the sub-goals or work packages of services pricing. Recently, the problem of hourly based pricing was apparently indicated in the work of Bos-de Vos et al. (2016, p. 1102) where a client refused to pay a professional fee of "150 Euros per hour" due to inadequate professional value perception and underestimation by the client. It is clear 
that time-based pricing without significant consideration of perceived professional value by clients could lead to pricing failure. It is therefore necessary to combine time-based pricing of consulting QS services with the clients' perceived value of the consultant quantity surveyor.

Business development is common in corporate organizations focusing on tangible products. However, QS consultancy firms have been lagging behind in business development. The lack of business development in construction-related firms like QS is indicative of their short life span as compared to manufacturing firms that survive over many decades. It is therefore necessary for QS professional services firms to undertake business development programs with emphasis on services pricing capability. The hypothesis testing in this study shows that business development is not dependent on the core professional competences for pricing QS consultancy services. Indeed, the core professional competences of QS consulting are related to the delivery of technical aspects of the project such as cost management. The professional core competences of QS are clearly indicated in RICS (2016), Cunningham (2014). The role of business development in competitive global business environment cannot be under estimated thus it is high time QS consultancy firms rethink their business development agenda.

\section{Professional Service cost management}

Professional service cost management is effective use of cost information obtained from budgetary planning and control throughout the four main phases of service cost management. The four phases include formulation of cost management strategies; communication of cost information to relevant units within the organization; and implementation, monitoring and evaluation of cost management strategies. Professional service cost management involves the planning and control of budgets of expenses during QS consultancy services provision to clients. Cost management is vital to QS services price formulation. In order to set a price QS professional service provision to clients, it is necessary to develop strategic competences. Strategic competences that must be developed include the time taken to solve problems (factor loading $=0.794$ ); materials used on the project (factor loading $=0.653$ ); good financial control system (factor loading $=0.805$ ); record of past project cost (factor loading $=0.618$ ); and accurate forecast of future cost (factor loading = 0.517). Professional QS consultancy firms that focus on the development of these strategic competences by training their employees in planning and work schedule management within available time allocated for the project will reduce the cost of providing services to clients. The management of consulting time allocated will create a domino effect on the amount of materials used for the delivery of services culminating into positive effect on the pricing of professional QS services. Similarly, the competence for the design of good financial control system leads to effective management of services cost. This creates the opportunity for low cost leadership for competitive advantage of QS consultancy firms. A good financial control system requires the availability of past records of services cost. For this to be achieved, it is necessary for QS consulting firms to develop the competences of their professionals to manage previous cost of services provided to clients.

\section{Service production capabilities}

Professional service delivery capabilities are the resources required by QS consultancy firms to provide services to clients efficiently. According to Jewell et al. (2014) professional service firms require technical skills to provide services to client. Competences cannot be developed without technical know-hows. It is in this direction that professional bodies and built environment educational institutions such as universities training in technical skills. Apparently missing in QS professional competence training, practice and theory is the integration of both strategic competences of and pricing of services. Technical competences supports provision of value- 
ECAM

25,3

468

based services to meet clients' expectations. A nexus between technical competence and financial capabilities drives the provision of value-based services to clients. Financial capability ensures prudent management of funds to create cost leadership for competitive pricing position. Within the ambit of both technical and financial capabilities, this study investigated production of timely reports (0.754); financial capacity (0.646); overhead and profit $(0.755)$; and technical capacity (0.546). Technical competences are required to produce reports to the satisfaction of clients. These reports must not only be expertly produced but delivered to the client within the scheduled time agreed in the consultancy contract.

Financial management competence is an important aspect of business management to the extent that it requires the involvement of an entire staff to ensure the provision of quality services at reduced cost (Taylor and Hensy, 1990). Financial competences involve capabilities for developing and forecasting competitive overhead and profits. Effective monitoring and control of overheads is a critical factor of financial management in construction professional services firms for their survivability (Yisa and Edwards, 2002). Overhead and profits are key ingredients for setting the final price for QS consultancy services provided to clients. Financial competences are required for pricing construction professional services. Yisa and Edwards (2002) in a study found that small-sized consulting engineering firms in their financial management graded fee collection higher than cash flow monitoring. However, in competitive globalized business environment, it is important that a holistic strategic financial management is pursued in all sizes of professional services firms.

It is apparent from the discussions that interrelationships exist among the variables of the common factors: business management; services cost management; and service production capabilities. The respective variables of the three common factors or components are categorized in to two main strategic streams: professional competence and business competence (Kubr, 2002) which are required to produce and deliver services to client. This phenomenon is demonstrated in Figure 1 which shows that firm experience; and duration to render service to client or timely production of reports plays a major role in both professional competence and business competence. Thus it is apparent to suggest that experience and time creates a nexus between professional competence and business competence of pricing consultant QS services (Table IV).

Figure 1.

A competence framework for strategic pricing of quantity surveying consultancy services

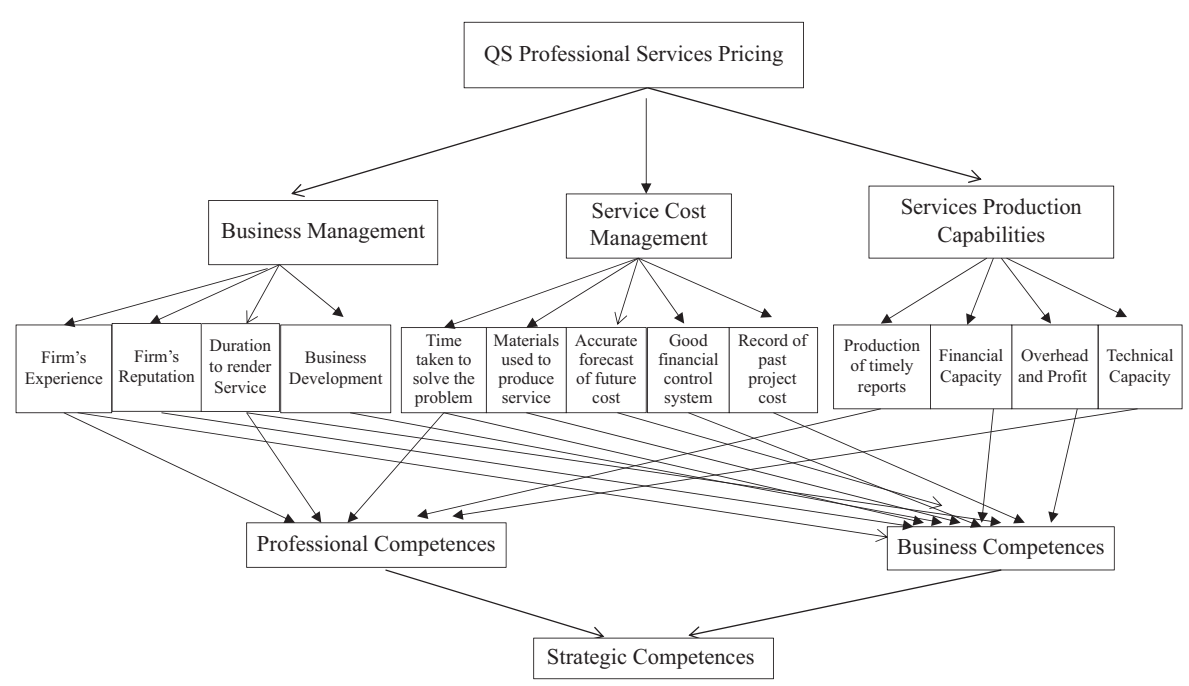


$\underline{\text { Description of components and variables }}$

Component 1: Business management

1. Firm's experience

2. Duration to render service

3. Business development

4. Firm's reputation

Component 2: Professional service cost management

1. Time taken to solve the problem

2. Materials used to produce service

3. Good financial control system

4. Record of past project cost

5. Accurate forecast of future cost

Component 3: Production capabilities

1. Production of timely reports

2. Financial capacity

3. Overhead and profit

4. Technical capacity
Factor loading

Variance explained (\%)

0.648

0.709

0.881

0.580

0.794

0.653

0.805

0.618

0.517

0.754

0.646

0.755

0.546
45.587

Strategic competences for pricing QS

469

Table IV.

Component of QS consultancy service pricing competences

\section{Conclusion}

This study sought to identify and establish the relationship between strategic competences and the pricing of professional QS consultancy services. The findings of the study uncovered key variables within the two main domains of strategic competences. These variables were also found to be significantly related to the pricing of professional QS consultancy services. It is obvious that the services sector globally is experiencing massive revolution and expansion. In view of the findings, it is suggested that strategic competences for pricing QS consultancy services are important variables for successful service delivery within value for money framework. This provides answers to nagging questions regarding the competitive pricing of professional QS professional services that create the willingness of clients to pay and competitive advantage for QS consultancy firms. While this study may not provide a conclusive answer to strategic pricing of QS professional services, it sets the platform for further studies to deepen, the theoretical and practical understanding of strategic pricing in QS profession which hitherto, has not been considered. These can be achieved by future studies focusing on the behavioral dimensions of pricing QS consultancy services. Also, in-depth studies in the future focusing on specific competences for time management in QS consultancy services delivery; strategic techniques for material and service cost management including a reappraisal of strategic competences for QS consulting services provision. Finally, it is recommended that QS professional bodies including policy makers and built environment educational administrators critically consider the managerial strategic competences during the design of curriculum, course materials and short courses for both professionals and students of higher institutions of learning.

\section{References}

Adesi, M. (2014), “A generic framework for consultancy services pricing: the case of quantity surveying practice", available at: ir.knust.edu.gh/xmlui/handle/123456789/6858 (accessed September 15, 2016).

Aly, W.O. (2016), "The learning organization: a foundation to enhance the sustainable competitive advantage of the service sector in Egypt", Journal of Public Management Research, Vol. 2 No. 2, pp. 37-62. 
ECAM

25,3

Analoui, F., Labbaf, H. and Noorbakhsh, F. (2000), "Identification of clusters of managerial skills for increased effectiveness: the case of steel industry in Iran", International Journal of Training and Development, Vol. 4 No. 3, pp. 217-234.

Anderson, D.W., Krajewski, H.T., Goffin, R.D. and Jackson, D.N. (2008), "A leadership self-efficacy and its relation to effective leadership", Leadership Quarterly, Vol. 19 No. 5, pp. 595-608.

Bakar, A.H.A., Tufail, M.A., Yusof., M.N. and Virgiyanti, W. (2011), "Implementation of strategic management practices in the Malaysian construction industry", Pakistan Journal of Commerce and Social Sciences, Vol. 5 No. 1, pp. 140-154.

Barney, J.B. (1991), "Firm resources and sustained competitive advantage", Journal of Management, Vol. 17 No. 1, pp. 99-120.

Bolstein, A.R. and Crow, M. (2008), "Statistical formulas and citations for EPA's 2007 ERP sample planner and ERP results analyzer", EPA Contract Number EP- W-04-023, Work Assignment 3-61, May 12.

Bolton, L.E. and Alba, J.W. (2006), "Price fairness: good and service differences and the role of vendor costs", Journal of Consumer Research, Vol. 33 No. 1, pp. 258-265.

Bos-de Vos, M., Volker, L. and Wamelink, H. (2016), "Real estate development by architectural firms: is the business model future-proof?", in Chan, P.W. and Neilson, C.J. (Eds), Proceedings of the 32nd Annual ARCOM Conference, Vol. 2, Association of Researchers in Construction Management, Manchester, pp. 1097-1106, September 5-7.

Brant, J., Dooley, R. and Iman, S. (2008), "Leadership succession: an approach to filling the pipeline", Strategic HR Review, Vol. 7 No. 4, pp. 17-24.

Calabrese, A. and De Francesco, F. (2014), "A pricing approach for service companies: service blueprint as a tool of demand-based pricing", Business Process Management Journal, Vol. 20 No. 6, pp. 906-921.

Chappelow, C. (1998), "360-degree feedback”, in McCauley, A., Moxley, R. and Van Velso, E. (Eds), The Handbook for Leadership Development, Jossey-Bass Publishers, San Francisco, CA, pp. 48-49.

Chen, C. (2012), "Organizational learning, competitive strategy and export performance", A Master Thesis Presented to the Massey University, Auckland, available at: mro.massey.ac.nz/xmlui/ bitstream/handle/10179/3894/01_front.pdf? (accessed August 2016).

Cheng, M.I., Dainty, A.R.J. and Moore, D.R. (2005), “What makes a good project manager?”, Human Resource Management Iournal, Vol. 15 No. 1, pp. 25-37.

Chisnall, P.M. (1982), "International marketing and purchasing of industrial goods: an interaction approach", Strategic Management Journal, Vol. 3 No. 4, pp. 383-384.

Chong, E. (2008), "Managerial competency appraisal: a cross-cultural study of American and East Asian managers", Journal of Business Research, Vol. 61 No. 3, pp. 191-200.

Cunningham, T. (2014), “The work and skills base of the quantity surveyor in Ireland-an introduction”, available via: arrow.dit.ie/cgi/viewcontent.cgi?article $=1034 \&$ context=beschreoth (accessed August 4, 2016).

Dainty, A.R.J., Cheng, M.I. and Moore, D.R. (2005), "Competency-based model for predicting construction project managers' performance", Lournal of Engineering in Management. ASCE, Vol. 21 No. 1, pp. 2-9.

Dainty, A.R.J., Cheng, M.I. and Moore, D.R. (2004), "A competency-based performance model for construction project managers", Construction Management and Economics, Vol. 22 No. 1, pp. 877-886.

Dainty, A.R.N., Cheng, M.-I. and Moore, D.R. (2003), "Redefining performance measures for construction project managers: an empirical evaluation", Construction Management and Economics, Vol. 21 No. 1, pp. 209-218. 
Dimov, D. and de Holan, P.M. (2010), "Firm experience and market entry by venture capital firms (1962-2004)”, Journal of Management Studies, Vol. 47 No. 1, pp. 130-161.

Docters, R., Reopel, M., Sun, J.M. and Tanny, S. (2004), "Capturing the unique value of services: why pricing of services is different”, Lournal of Business Strategy, Vol. 25 No. 2, pp. 23-28.

Dulaimi, M.F. and Langford, D. (1997), "Job behaviour of construction project managers: determination and assessment", Lournal of Construction Engineering and Management. ASCE, Vol. 125 No. 4, pp. 256-264.

Dwyer, F.R. and Tanner, J.F. (2006), Business Marketing: Connecting Strategy, Relationship and Learning, 3rd ed., McGraw- Hill/Irwin, New York, NY.

Ehrhardt, A. and Nippa, M. (2005), "Far better than nothing at all: towards a contingency-based evaluation of management consulting services", Working Papers, No. 2005, 09, Freiberg, available at: http://hdl.handle.net/10419/27092 (accessed November 2015).

Eisenhardt, K.M. and Martin, J.A. (2000), "Dynamic capabilities: what are they?”, Strategic Management Journal, Vol. 21 Nos 10/11, pp. 1105-1121.

Ernst, B. and Kieser, A. (2005), "Far better than nothing at all -towards a contingency-based evaluation of management consulting services", Working Papers. No. 09, Faculty of Economics and Business Administration, Technical University Bergakademie, Freiberg, available at: tu-freiberg.de/sites/default/files/media/fakultaet-6-3307/.../nippa_9_2005.pdf (accessed October 20, 2016).

Farr, J.V. and Fellow, P.E. (2001), "Commodities and value-based pricing of engineering services", Journal of Management in Engineering, Vol. 17 No. 4, pp. 224-228.

Flyvbjerg, B., Holm, M.K.S. and Buhl, S.K. (2003), "How common and how large are cost overruns in transport infrastructure projects?", Transport Reviews, Vol. 23 No. 1, pp. 71-88.

Gibb, S. (2003), "Information, advice and guidance - is it time for a national research forum", Career Development International, Vol. 8 No. 4, pp. 169-218.

Haider, T. (2009), "Financial management of construction contracts, constructability and its relation with TQM, cost shifting risk and cost/benefit", International Research Journal of Finance and Economics, ISSN 1450-2887, No. 28, pp. 42-51, available at: www. internationalresearchjournaloffinanceandeconomics.com/ISSUES/IRJFE $\% 20$ issue $\% 2028$.htm (accessed December 14, 2014).

Hamilton, B. (2008), "Taking the efficiency utility model to the next level", Paper presented at the ACEEE summer study on energy efficiency in buildings, Pacific Grove, CA, August 17-22.

Harison, E. and Boonstra, A. (2009), "Essential competencies for technochange management: towards an assessment model", International Iournal of Information Management, Vol. 29 No. 1, pp. 283-294.

Hjorth, J. and Röström, J. (2012), "Procurement strategies for technical consultancy services: practitioner perceptions and best practice cases", Master of Science Thesis, Department of Technology Management and Economics, Division of Service Management, Chalmers University of Technology, Gothenburg.

Hodgson, G.M. (1998), "Evolutionary and competence-based theories of the firm”, Journal of Economic Studies, Vol. 25 No. 1, pp. 25-56.

Hubbert, A.R., Sehorn, A.G. and Brown, S.W. (1995), "Service expectations: the consumer versus the provider", International Iournal of Service Industrv Management, Vol. 6 No. 1, pp. 6-21.

Intagliata, J., Ulrich, D. and Smallwood, N. (2000), "Leveraging leadership competencies to produce leadership brand: creating distinctiveness by focusing on strategy and results", Human Resources Planning, Vol. 23.4 No. 1, pp. 12-23.

International Finance Corporation (2007), Stakeholder Engagement: A Good Practice Handbook for Companies Doing Business in Emerging Markets, IFC, Washington, DC. 
ECAM

25,3

472

Jenkins, N. (2006), "A project management primer", available at: www.nickjenkins.net/prose/ projectPrimer.pdf (accessed June 20, 2015).

Jewell, C.A., Flanagan, R. and Lu, W. (2014), "The dilemma of scope and scale for construction professional service firms", Construction Management and Economics, Vol. 32 No. 5, pp. 473-486.

Kallay, B. (2012), "Evolutionary and competence-based theories of the firm", Lournal of International Studies, Vol. 5 No. 1, pp. 38-45.

Kish, L. (1965), Survey Sampling, John Wiley \& Sons, Inc., New York, NY.

Kothari, A. and Lackner, J. (2006), "A value based approach to management", Supply Chain Management: An International Journal, Vol. 21 No. 4, pp. 243-249.

Kubr, M. (2002), Management Consulting: A Guide to the Profession, 4th ed., International Labour Office, Geneva.

Lee, M.-J. and Lee, D.-H. (2015), "Effects of Hpwss on employee' attitude for Korean firms: the mediating role of human resource competency and the moderating role of organization culture", The Journal of Applied Business Research, Vol. 31 No. 6, pp. 2225-2236.

Lehtinen, U. and Järvinen, R. (2015), "The role of service characteristics in service innovations”, Nordic Journal of Business, Vol. 64 No. 3, pp. 168-181.

Lei, D., Hitt, M.A. and Bettis, R. (1996), "Dynamic core competences through a-Learning and strategic context", Lournal of Management, Vol. 22 No. 4, pp. 549-569.

Lewis, M.A. (1995), "Competence analysis and the strategy process", $\mathrm{PhD}$ thesis, University of Cambridge, Cambridge.

Lewis, M.A. (2003), "Analysing organisational competence: implications for the management of operations", International Journal of Operations and Production Management, Vol. 23 No. 4, pp. 731-756.

McAfee, R.P. (2008), "Price discrimination", in Wayne, D.C. and Angland, J. (Eds), Issues in Competition Law and Policy, ABA Section of Antitrust Law, Chicago, pp. 465-484.

McIvor, R. (2000), "A practical framework for understanding the outsourcing process", Supplv Chain Management, Vol. 5 No. 1, pp. 22-36.

Meehan, J., Davenport, C. and Kahlon, S. (2012), "The price of pricing effectiveness: Is the view worth the climb?", Deloitte Review, No. 11, pp. 19-29, available at: www2.deloitte.com/.../the-price-ofpricing-effectiveness-is-the-view-worth-the

Meissner, J. and Strauss, A.K. (2010), "Improved bid prices for choice-based network revenue management”, Department of Management Science, Lancaster University Management School, available at: eprints.lancs.ac.uk/48983/1/Document.pdf (accessed October 16, 2015).

Mills, J.K. and Lewis, M.A. (1997), "Competitive analysis in a central research organisation: lessons from practice", in Ribera, J. and Prats, J. (Eds), Managing Service Operations: Lessons from the Service and Manufacturing Sectors, Proceedings of the European Operations Management Association Conference, IESE, Barcelona, pp. 581-586, June, 16-18.

Mohr, L.A. and Bitner, M.J. (1991), "Mutual understanding between customers and employees in service encounters", in Holman, R.H. and Solomon, M.R. (Eds), Advances in Consumer Research, Association for Consumer Research, Provo, UT, pp. 611-617, Vol. 18.

Nagle, T.T., Hogan, J.E. and Zale, J. (2016), The Strategy and Tactics of Pricing, Routledge, London.

Nalewaik, A. (2012), "Qualifications and barriers to professional recognition in cost engineering", ICEC 8th World Congress Proceedings, June 23-27.

Nelson, R.R. and Winter, S.G. (1982), An Evolutionary Theory of Economic Change, Harvard University Press, Cambridge, MA.

Nikumbh, A.R. and Pimplikar, S.S. (2014), "Role of project management consultancy in construction project", Iournal of Mechanical and Civil Engineering, Vol. 10 No. 6, pp. 14-19. 
Ostrom, A.L., Bitner, M.J., Brown, S.W., Burkhard, K.A., Goul, M., Smith-Daniels, V. and Rabinovich, E. (2010), "Moving forward and making a difference: research priorities for the science of service", Journal of Service Research, Vol. 13 No. 1, pp. 4-36.

Patanakul, P. and Milosevic, D. (2008), "A competency model for effectiveness in managing multiple projects”, The Journal of High Technology Management Research, Vol. 18 No. 2, pp. 118-131.

Perreault, W.D.J. and McCarthy, E.J. (2002), Basic Marketing: A Global-Managerial Approach, McGraw-Hill/Irwin, New York, NY.

Porter, M.E. (1998), Competitive Strategy: Techniques for Analysing Industry and Competitors, The Free Press, New York, NY.

Prahalad, C.K. and Hamel, G. (1990), "The core competences of the corporation”, Harvard Business Review, May-June, pp. 79-91.

Reguant, M. (2011) "The welfare effects of complementary bidding mechanisms: an empirical analysis of the Spanish wholesale electricity market”, MIT Job Market Paper, available at: http:// economics.mit.edu/grad/mreguant/research (accessed November 1, 2015).

RICS (2016), "Business and management”, available at: www.rics.org/ie/tag/business-management/ (accessed August 20, 2016).

Rugman, A.M. and Verbeke, A. (2002), "Edith Penrose's contribution to the resource-based view of strategic management", Strategic Management Journal, Vol. 23 No. 8, pp. 769-780.

Russell, J.S., Hanna, A., Bank, L.C. and Shapira, A. (2007), "Education in construction engineering and management built on tradition: blueprint for tomorrow", Journal of Construction Engineering and Management, Vol. 133 No. 9, pp. 661-668.

Selfano, O.F., Adero, P. and Chumba, S. (2014), "Integrated financial management information system and its effect on cash management in Eldoret West District Treasury, Kenya", International Journal of Business and Social Science, Vol. 5 No. 8, pp. 31-37.

Silva, D.L., Sabino, L.D., Lanuza, D.M., Adina, E.M., Villaverde, B.S. and Pena, E.G. (2014), "Silva's management competency theory: a factor-item analytic approach utilizing oblique rotation direct oblimin method under Kaiser-Bartlett's test of sphericity", Proceedings of the World Congress on Engineering and Computer Science 2014 Vol. I WCECS 2014, San Francisco, CA, October 22-24.

Skipper, C.O. and Lansford, C.B. (2006), "Assessment with 360 degrees evaluations of leadership behaviour in construction project managers", Lournal of Management in Engineering, Vol. 22 No. 2, pp. $75-80$.

Sparrow, P.R. and Hodgkinson, G.P. (2006), "What is strategic competence and does it matter? exposition of the concept and a research agenda", CAHRS Working Paper No. 06-16, Cornell University, School of Industrial and Labor Relations, Center for Advanced Human Resource Studies, Ithaca, NY, available at: http://digitalcommons.ilr.cornell.edu/cahrswp/458 (accessed February 19, 2017).

Sporrong, J. (2011), "Criteria in consultant selection: public procurement of architectural and engineering services", Australasian Journal of Construction Economics and Building, Vol. 11 No. 4, pp. 59-76.

Taylor, D.H. and Hensy, M. (1990), "Financial issues in engineering management: interview", Journal of Management in Engineering. ASCE, Vol. 6 No. 2, pp. 157-161.

The World Bank (2002), Consulting Services Manual: A Comprehensive Guide to Selection of Consultants, The World Bank, Washington, DC.

Uddin, S.M. and Arafat, S.M.Y. (2016), "A review of review”, International Journal of Perceptions in Public Health, Vol. 1 No. 1, pp. 14-24.

Vaculik, M., Prochazka, J. and Smutny, P. (2014), "Competencies and leadership effectiveness: which skills predict effective leadership?", Visnja Grozdanic, Proceedings of the 10th European Conference on Management Leadership and Governance, Academic Conferences and Publishing International Limited, Reading, ISBN 978-1-910309-75-9. 
ECAM

25,3
Williams, B., Brown, T. and Onsman, A. (2012), "Exploratory factor analysis: a five-step guide for novices", Australasian Journal of Paramedicine, Vol. 8 No. 3, pp. 1-13.

Yisa, S. and Edwards, D.J. (2002), "Evaluation of business strategies in the UK construction engineering consultancy", Measuring Business Excellence, Vol. 6 No. 1, pp. 23-31.

\section{Further reading}

Cheng, M.I., Dainty, A.R.J. and Moore, D.R. (2003), "The differing faces of managerial competency in Britain and America", Lournal of Management Development, Vol. 22 No. 6, pp. 527-537.

Dulaimi, M.F. and Langford, D. (1997), "Job behaviour of construction project managers: determination and assessment", Journal of Construction Engineering and Management. ASCE, Vol. 125 No. 4, pp. 256-264.

Patsula, P.J. (2007), The Entrepreneur's Guidebook, Patsula Media, Edmonton, Alberta, available at: www.smbtn.com/books/gb46.pdf (accessed November 13, 2015).

\section{Corresponding author}

Michael Adesi can be contacted at: adesimichael@yahoo.com 